\title{
Porphyrobacter cryptus sp. nov., a novel slightly thermophilic, aerobic, bacteriochlorophyll a-containing species
}

\author{
Fred A. Rainey, ${ }_{1}$ Joana Silva, ${ }^{2}$ M. Fernanda Nobre, ${ }^{2}$ Manuel T. Silva ${ }^{3}$ \\ and Milton S. da Costa ${ }^{4}$ \\ ${ }^{1}$ Department of Biological Sciences, Louisiana State University, Baton Rouge, LA 70803, USA \\ ${ }^{2,4}$ Departamento de Zoologia ${ }^{2}$ and Departamento de Bioquímica ${ }^{4}$, Universidade de Coimbra, \\ 3004-517 Coimbra, Portugal \\ ${ }^{3}$ Instituto de Biologia Molecular e Celular, Universidade do Porto, R. do Campo Alegre, 4150 \\ Porto, Portugal
}

Correspondence

Milton S. da Costa

milton@ci.uc.pt

Two strains of a novel aerobic, bacteriochlorophyll a-containing species of the $\alpha-4$ subclass of the Proteobacteria were isolated from the hot spring at Alcafache in central Portugal. 16S rRNA gene sequence-based phylogenetic analyses showed the two novel isolates to be phylogenetically related to members of the genera Erythrobacter, Erythromicrobium and Porphyrobacter. The strains produce reddish-orange-pigmented colonies, have an optimum growth temperature of about $50{ }^{\circ} \mathrm{C}$ and could be distinguished from the species Porphyrobacter tepidarius, which also has a high growth temperature, primarily on the basis of the fatty acid composition. The novel species does not grow anaerobically in the presence or absence of a light source. The strains of the novel species utilize several single carbon sources for growth, most of which are also used by $P$. tepidarius. The species status of strains ALC- $2^{\top}$ and ALC-3 was confirmed by low reassociation values of the DNA with species of the genera Erythrobacter, Erythromicrobium and Porphyrobacter. Phenotypic characteristics and $16 \mathrm{~S}$ rRNA gene sequence analyses also show that strains ALC-2 ${ }^{\top}$ (=DSM $12079^{\top}=$ ATCC BAA-386 $^{\top}$ ) and ALC-3 (=DSM 12080) represent a novel species, for which the name Porphyrobacter cryptus sp. nov. is proposed.

\section{INTRODUCTION}

Many species within the $\alpha$-subclass of the Proteobacteria synthesize bacteriochlorophyll $a(\mathrm{Bchl} a)$ under aerobic conditions. Photoautotrophic growth under anaerobic or aerobic conditions has not been shown in these organisms, although some organisms may be photoheterotrophic under a limited range of cultivation conditions (Takamiya et al., 1987). Many of these organisms are exclusively chemoorganotrophic, leading to the view that the organisms are photoheterotrophic under unknown growth conditions. The $\alpha-4$ subclass of the Proteobacteria comprises the Bchl a-containing species of the genera Erythrobacter (Shiba \&

Abbreviation: Bchl a, bacteriochlorophyll a.

The GenBank/EMBL/DDBJ accession numbers for the 16S rRNA gene sequences of strain ALC-2 ${ }^{\top}$, Erythrobacter longus DSM $6997^{\top}$, Erythrobacter litoralis DSM 8509 ${ }^{\top}$, Erythromicrobium ramosum DSM $8510^{\top}$, Porphyrobacter neustonensis DSM $9434^{\top}$ and Porphyrobacter tepidarius DSM $10594^{\top}$ are respectively AF465834-AF465839.

TLC profiles of pigments of the novel isolates and reference species are available as supplementary material in IJSEM Online (http:// ijs.sgmjournals.org/).
Simidu, 1982; Yurkov et al., 1994), Erythromicrobium (Yurkov et al., 1994) and Porphyrobacter (Fuerst et al., 1993; Hanada et al., 1997), Erythromonas (Yurkov et al., 1997) and Sandaracinobacter (Yurkov et al., 1997). The species Erythrobacter longus and Erythrobacter litoralis originate from marine samples, are slightly halophilic and multiply by binary fission. The species Erythromicrobium ramosum also grows by binary fission, but, as the name implies, this organism can form slightly branching cells. The species Porphyrobacter neustonensis, unlike the other Bchl $a$-synthesizing bacteria of the $\alpha-4$ subclass of the Proteobacteria, produces unusual pleomorphic cells, some of which have stalk-like structures and reproduce by budding. The other species of this genus, Porphyrobacter tepidarius, produces short, ovoid, rod-shaped cells, divides by binary fission and has an optimum growth temperature of about $45-50{ }^{\circ} \mathrm{C}$. Another species, invalidly described as 'Citromicrobium bathyomarinum', was isolated from an abyssal hot-spring plume, is mesophilic, yellow-pigmented, contains Bchl $a$ under aerobic growth and forms pleomorphic cells that resemble those of Erythromicrobium ramosum (Yurkov et al., 1999). Other strains closely related to the genera Erythrobacter, Erythromicrobium and Porphyrobacter 
have been isolated, but these have not been characterized, although 16S rRNA gene sequences have been placed in public databases and can be used for phylogenetic analysis.

We recently isolated several slightly thermophilic, reddishorange-pigmented organisms from a hot spring, in central Portugal, with a vent temperature of $50{ }^{\circ} \mathrm{C}$. These organisms produced $\mathrm{Bchl} a$ under aerobic conditions, and phylogenetic analysis indicated that strains $\mathrm{ALC}-2^{\mathrm{T}}$ and ALC-3 were closely related to the species of the genera Erythrobacter, Erythromicrobium and Porphyrobacter. Phylogenetic, physiological, biochemical and chemotaxonomic characteristics of the novel slightly thermophilic strains showed that these isolates belonged to a novel species. However, our study also indicated that the species Erythrobacter longus and Erythrobacter litoralis, Erythromicrobium ramosum and $P$. neustonensis and $P$. tepidarius possess few, if any, known characteristics that distinguish these organisms at the genus level. It is necessary to re-examine the taxonomic relationships of the genera Erythrobacter, Erythromicrobium and Porphyrobacter, but it cannot be done at this stage. We propose, therefore, that strains ALC- $2^{\mathrm{T}}$ and ALC-3 should be included in the genus Porphyrobacter under the name Porphyrobacter cryptus sp. nov. because this organism has phenotypic characteristics that most resemble those of P. tepidarius.

\section{METHODS}

Isolation and bacterial strains. Strains $\mathrm{ALC}-2^{\mathrm{T}}$ and ALC- 3 were isolated from the run-off of the hot spring located at Alcafache in central Portugal. Water samples were transported without temperature control and filtered, the same day, through membrane filters (Gelman type GN-6, pore size $0 \cdot 45 \mu \mathrm{m}$, diameter $47 \mathrm{~mm}$ ). The filters were placed on the surface of Thermus and $\mathrm{R}_{3} \mathrm{~A}$ media solidified with agar $(2 \%, w / v)$ (Reasoner \& Geldreich, 1985; Williams \& da Costa, 1992). The plates containing the filters were wrapped in plastic bags and incubated at 45 or $50{ }^{\circ} \mathrm{C}$ for up to 3 days. Cultures were purified by subculturing on Thermus medium and were maintained at $-70{ }^{\circ} \mathrm{C}$ in the same medium with $15 \%$ glycerol. The type strains of Erythrobacter longus (DSM $6997^{\mathrm{T}}$ ), Erythrobacter litoralis (DSM $8509^{\mathrm{T}}$ ), Erythromicrobium ramosum (DSM 8510 ${ }^{\mathrm{T}}$ ), P. neustonensis (DSM 9434 ${ }^{\mathrm{T}}$ ) and P. tepidarius (DSM 10594 ${ }^{\mathrm{T}}$ ) were obtained from the Deutsche Sammlung von Mikroorganismen und Zellkulturen (DSMZ), Braunschweig, Germany, and used for comparative purposes.

Morphological, biochemical and tolerance characteristics. Cultures were grown routinely in PE medium, described by Hanada et al. (1997), containing the following $\left(1^{-1}\right)$ : sodium glutamate $(0.5 \mathrm{~g})$, sodium succinate $(0.5 \mathrm{~g})$, sodium acetate $(0.5 \mathrm{~g})$, yeast extract $(0.5 \mathrm{~g})$, Casamino acids $(0.5 \mathrm{~g}), \mathrm{Na}_{2} \mathrm{~S}_{2} \mathrm{O}_{3} \cdot 5 \mathrm{H}_{2} \mathrm{O}(0.5 \mathrm{~g}), \mathrm{KH}_{2} \mathrm{PO}_{4}(0.38 \mathrm{~g})$, $\mathrm{K}_{2} \mathrm{HPO}_{4}(0.39 \mathrm{~g}),\left(\mathrm{NH}_{4}\right)_{2} \mathrm{SO}_{4}(0.5 \mathrm{~g})$, basal salts solution $(5 \mathrm{ml})$ and a vitamin solution $(1 \mathrm{ml})$. The basal salts medium contained the following $\left(\mathrm{l}^{-1}\right)$ : $\mathrm{FeSO}_{4} \cdot 7 \mathrm{H}_{2} \mathrm{O}(1 \cdot 1 \mathrm{~g}), \mathrm{MgSO}_{4} \cdot 7 \mathrm{H}_{2} \mathrm{O}(24 \cdot 6 \mathrm{~g}), \mathrm{CaCl}_{2} \cdot 2 \mathrm{H}_{2} \mathrm{O}$ $(2 \cdot 9 \mathrm{~g}), \quad \mathrm{NaCl}(23 \cdot 4 \mathrm{~g}), \quad \mathrm{MnSO}_{4} \cdot 4 \mathrm{H}_{2} \mathrm{O} \quad(146 \cdot 5 \mathrm{mg}), \quad \mathrm{ZnSO}_{4} \cdot 7 \mathrm{H}_{2} \mathrm{O}$ $(28 \cdot 8 \mathrm{mg}), \quad \mathrm{Co}\left(\mathrm{NO}_{3}\right)_{2} \cdot 6 \mathrm{H}_{2} \mathrm{O} \quad(29 \cdot 2 \mathrm{mg}), \quad \mathrm{CuSO}_{4} \cdot 5 \mathrm{H}_{2} \mathrm{O} \quad(25 \cdot 2 \mathrm{mg})$, $\mathrm{Na}_{2} \mathrm{MoO}_{4} \cdot 2 \mathrm{H}_{2} \mathrm{O}(24 \cdot 2 \mathrm{mg}), \mathrm{H}_{3} \mathrm{BO}_{3}(31 \cdot 0 \mathrm{mg})$ and EDTA $(4 \cdot 5 \mathrm{~g})$. The vitamin solution contained the following (per $100 \mathrm{ml}$ ): nicotinic acid $(100 \mathrm{mg})$, thiamine hydrochloride $(100 \mathrm{mg})$, biotin $(5 \mathrm{mg})$, $p$-aminobenzoic acid $(50 \mathrm{mg})$, vitamin $\mathrm{B}_{12} \quad(1 \mathrm{mg})$, pyridoxine hydrochloride $(50 \mathrm{mg})$, pantothenic acid $(50 \mathrm{mg})$ and folic acid $(50 \mathrm{mg})$; it was sterilized by filtration and added to the autoclaved medium after cooling.

Electron microscopy was performed on exponential-phase cells fixed with aqueous $4 \%$ paraformaldehyde, $1 \cdot 25 \%$ glutaraldehyde and $10 \mathrm{mM}$ calcium chloride at room temperature. The cells were washed by centrifugation after $4 \mathrm{~h}$ with $50 \mathrm{mM}$ cacodylate buffer supplemented with $10 \mathrm{mM}$ calcium chloride $(\mathrm{pH} 6 \cdot 4)$ and fixed at room temperature for $2 \mathrm{~h}$ with osmium tetroxide in veronal-acetate buffer containing $10 \mathrm{mM}$ calcium chloride (Silva \& Macedo, 1983, 1987). Samples were embedded in Epon resin after dehydration in ethanol. The sections were contrasted with uranyl acetate followed by lead citrate. Cells were visualized and photographed with a Zeiss EM $10 \mathrm{C}$ electron microscope. Cell dimensions and motility were determined by phase-contrast microscopy; the number and position of flagella were visualized by light microscopy after staining of the cells with the Ryu stain (Heimbrook et al., 1989).

The growth temperature range of strain $\mathrm{ALC}-2^{\mathrm{T}}$ was examined by measuring the turbidity $(610 \mathrm{~nm})$ of cultures incubated in $300 \mathrm{ml}$ metal-capped Erlenmeyer flasks, containing $100 \mathrm{ml} \mathrm{PE}$ medium, in a reciprocal water-bath shaker. The $\mathrm{pH}$ range for growth was examined at $50{ }^{\circ} \mathrm{C}$ in the same medium as described previously by Moreira et al. (2000).

All biochemical and tolerance tests were performed, as described previously (Santos et al., 1989), in PE liquid medium or PE medium solidified with agar at the optimum growth temperature for up 5 days. Single-carbon-source assimilation tests were performed in a minimal medium composed of PE salts, vitamin solution and filter-sterilized carbon sources $\left(2 \cdot 0 \mathrm{~g} \mathrm{l}^{-1}\right)$, but without the other organic components. Growth was examined daily by measuring the turbidity of cultures incubated in $20 \mathrm{ml} \mathrm{screw}$-capped tubes containing $10 \mathrm{ml}$ medium for a total of 5 days. Positive and negative control cultures were grown in $\mathrm{PE}$ medium and in minimal medium without a carbon source. Anaerobic growth was assessed in cultures grown in the basal salts of $\mathrm{PE}$ medium incubated in anaerobic chambers with an $\mathrm{H}_{2} / \mathrm{CO}_{2}$ atmosphere.

Polar lipid, lipoquinone and fatty acid composition. Cultures used for polar lipid and lipoquinone analyses were grown at the optimum growth temperature until the exponential phase of growth. The cells were recovered by centrifugation, polar lipids were extracted and the individual polar lipids were separated by one-dimensional TLC as described previously (Prado et al., 1988).

Lipoquinones were extracted from freeze-dried cells, purified by TLC and separated with a Gilson HPLC apparatus by using a reverse-phase column (RP18, Spherisorb, S5 ODS2) with methanol/heptane (10:2, $\mathrm{v} / \mathrm{v}$ ) as the mobile phase and were detected at $269 \mathrm{~nm}$ (Tindall, 1989).

Cultures for fatty acid analysis were grown on agar plates, in sealed plastic bags submerged in a water bath, at their optimum growth temperatures for $24 \mathrm{~h}$. Fatty acid methyl esters were obtained from fresh wet biomass and analysed as described previously (Moreira et al., 2000) using the MIS Library Generation software (Microbial ID).

Analysis of bacteriochlorophyll and carotenoids. Cultures in the exponential phase of growth were washed twice by centrifugation using a MOPS buffer (MOPS-NaOH, $0 \cdot 01 \mathrm{M} ; \mathrm{KCl}, 0 \cdot 1 \mathrm{M} ; \mathrm{MgCl}_{2}$, $0.001 \mathrm{M} ; \mathrm{pH} 7.5)$ and disrupted by sonication with a Vibra Cell100w sonicator (Sonics \& Materials). The disrupted suspension was centrifuged to sediment cells and debris and the absorption spectrum of the supernatant was examined on a Jasco spectrophotometer (model 7800). Bacteriochlorophylls were also extracted with acetone/methanol $(7: 2, \mathrm{v} / \mathrm{v})$. 
Carotenoids were extracted with chloroform/methanol, as described by Liaaen-Jensen \& Jensen (1971), in the dark to avoid photo-oxidation of the pigments. TLC was performed on silica gel G plates (no. 5626; Merck) using a solvent system composed of chloroform/methanol $(95: 12 \cdot 5, \mathrm{v} / \mathrm{v})$.

Determination of $\mathbf{G}+\mathbf{C}$ content of DNA, DNA-DNA reassociation studies and 165 rDNA sequence determination and phylogenetic analyses. The DNA was isolated as described by Cashion et al. (1977). The G+C content of the DNA was determined by HPLC as described by Mesbah et al. (1989). DNA for DNA-DNA reassociation studies was extracted and purified by the procedure of Marmur (1961). The degree of DNA reassociation was determined spectrophotometrically from the initial renaturation rates, according to De Ley (1970). Renaturation rates were measured in $1 \times \operatorname{SSC}(0 \cdot 15 \mathrm{M} \mathrm{NaCl}$ and $0 \cdot 015 \mathrm{M}$ trisodium citrate at $\mathrm{pH} 7 \cdot 0)$ using a Uvikon 940 spectrophotometer (Kontron) equipped with a thermostat-controlled cuvette chamber. The optimal renaturation temperature used in each case was calculated from the $\mathrm{G}+\mathrm{C}$ content (De Ley, 1970). Each hybridization experiment was performed at least twice.

Extraction of genomic DNA for 16S rRNA gene sequence determination, PCR amplification of the 16S rRNA gene and sequencing of purified PCR products were carried out as described previously (Rainey et al., 1996). Purified reactions were electrophoresed using a model 310 Genetic Analyzer (Applied Biosystems). The 16S rRNA gene sequences determined in this study were aligned against representative reference sequences of members of the Proteobacteria by using the ae2 editor (Maidak et al., 1999). The method of Jukes \& Cantor (1969) was used to calculate evolutionary distances. Phylogenetic dendrograms were generated using various treeing algorithms contained in the PHYLIP package (Felsenstein, 1993).

\section{RESULTS AND DISCUSSION}

\section{Morphological, physiological and biochemical characteristics}

The hot spring at Alcafache in central Portugal has a vent temperature of about $50 \cdot 6^{\circ} \mathrm{C}$ and a $\mathrm{pH}$ of $8 \cdot 3$. Strains ALC- $2^{\mathrm{T}}$ and ALC-3 formed reddish-orange-pigmented colonies, similar to those of the species of Erythrobacter, Porphyrobacter and Erythromicrobium. The two novel isolates had optimum growth temperatures between 50 and $55^{\circ} \mathrm{C}$, which were slightly higher than that of the type strain of $P$. tepidarius (Fig. 1). The higher growth temperature range of strains ALC- $2^{\mathrm{T}}$ and ALC-3 was particularly noticeable at supraoptimal temperatures, since the novel organism grew at $55^{\circ} \mathrm{C}$ while $P$. tepidarius did not. Strains ALC- $2^{\mathrm{T}}$ and ALC-3 had a $\mathrm{pH}$ range for growth between $6 \cdot 0$ and $9 \cdot 0$, with an optimum $\mathrm{pH}$ for growth between $7 \cdot 5$ and $8 \cdot 0$.

The strains formed short, rod-shaped cells of variable width $(0 \cdot 7-1 \cdot 4 \mu \mathrm{m})$ and length $(1 \cdot 0-2 \cdot 8 \mu \mathrm{m})$ during exponential phase in liquid cultures. The cells were motile by means of one polar flagellum. The ultrastructure of strain ALC $-2^{\mathrm{T}}$ was typical of a bacterium with a Gram-negative cell envelope (Fig. 2). The organism has an envelope consisting of a cytoplasmic membrane without invaginations or other internal membrane systems, a thin electron-dense peptidoglycan layer and an outer, convoluted outer membrane. Lipid

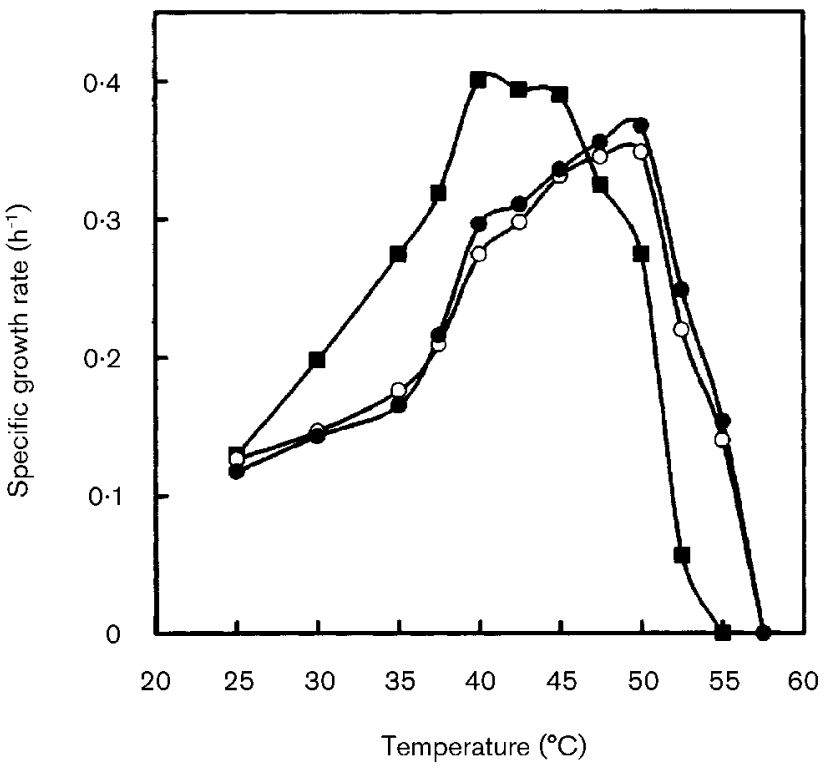

Fig. 1. Effect of temperature on the growth rates of the type strain of $P$. tepidarius $(\boldsymbol{\square})$, strain ALC- $2^{\top}(\bullet)$ and strain ALC-3 $(\bigcirc)$.

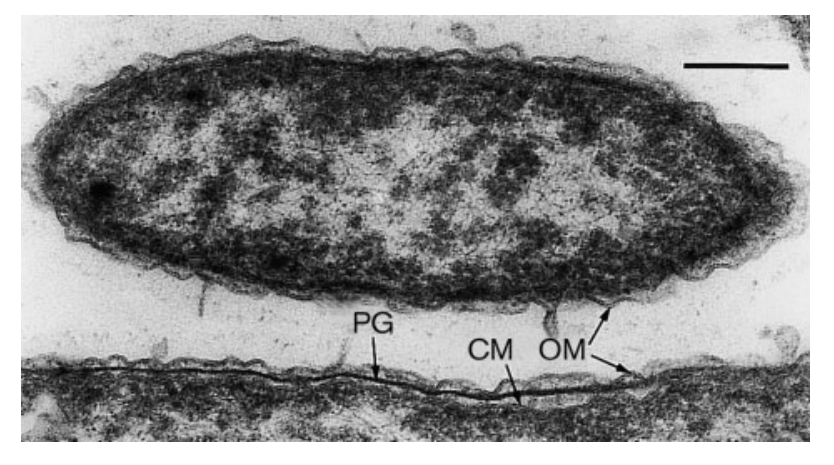

Fig. 2. Transmission electron micrograph of a section of strain ALC- $2^{\top}$ fixed with aldehyde/osmium tetroxide/uranyl acetate. OM, Outer membrane of the cell wall; PG, peptidoglycan layer of the cell wall; $\mathrm{CM}$, cytoplasmic membrane. Bar, $0.3 \mu \mathrm{m}$.

(poly- $\beta$-hydroxyalkanoates) and polyphosphate inclusions were also present. The type strain of $P$. tepidarius and strains ALC- $2^{\mathrm{T}}$ and ALC- 3 were cytochrome oxidase- and catalasepositive, growth was not observed under anaerobic conditions, nitrate was not reduced and they had almost identical phenotypic characteristics (Table 1).

\section{Polar lipid, quinone, fatty acid and Bchl composition}

Strains ALC $-2^{\mathrm{T}}$ and ALC-3, as well as the type strains of the species of Erythrobacter, Porphyrobacter and Erythromicrobium, 
Table 1. Phenotypic characteristics that distinguish $P$. tepidarius from strain ALC- $2^{\top}$ in minimal PE medium at their optimum growth temperatures

Results for strain ALC-3 were identical to those shown for strain ALC $-2^{\mathrm{T}}$. Both taxa degraded gelatin, arbutin and Tweens 20, 40 and 60; both taxa assimilated glucose, maltose, sucrose, cellobiose, pyruvate, glutamate and arginine; neither taxon assimilated fructose, galactose, mannose, L-sorbose, lactose, trehalose, D-xylose, D- or L-arabinose, L-sorbose, L-fucose, L-rhamnose, raffinose, melibiose, melezitose, ribose, lyxose, D- or L-arabitol, xylitol, i-erythritol, glycerol, sorbitol, myo-inositol, ribitol, galactitol, malate, acetate, citrate, succinate, $\alpha$-ketoglutarate, $N$-acetylglucosamine, salicin, serine, asparagine, proline or glutamine.

\begin{tabular}{|lcc|}
\hline Characteristic & P. tepidarius & ALC-2 $^{\mathbf{T}}$ \\
\hline Degradation of: & - & \\
Xylan & - & + \\
Starch & - & + \\
Aesculin & & - \\
Assimilation of: & + & - \\
Turanose & - & - \\
L-Xylose & + & - \\
Acetate & & \\
\hline
\end{tabular}

had identical polar lipid patterns, dominated by phosphatidylethanolamine (results not shown). The major respiratory quinone was ubiquinone 10 . The major fatty acids of strains
ALC- $2^{\mathrm{T}}$ and ALC-3, P. neustonensis, P. tepidarius, Erythrobacter litoralis, Erythrobacter longus and Erythromicrobium ramosum were unsaturated; however, there were large differences in the fatty acid compositions of the organisms (Table 2). In all

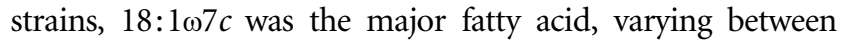
$33.5 \%$ in Erythromicrobium ramosum and $72 \%$ of the total fatty acids in Erythrobacter litoralis. The hydroxy fatty acid 14:0 2-OH was present in all strains, while 15:0 2-OH was detected in the two ALC isolates, Erythrobacter longus and Erythromicrobium ramosum. An unidentified fatty acid, with an equivalent chain-length of $17 \cdot 607$, was detected only in the type strains of P. neustonensis and Erythrobacter longus.

All of the strains examined produced Bchl $a$ aerobically in the dark and had identical absorption spectra, with a small peak at about $800 \mathrm{~nm}$ and a larger peak at about $870 \mathrm{~nm}$, characteristic of Bchl $a$ (Fig. 3). Acetone/methanol extracts had an absorption peak centred at about $770 \mathrm{~nm}$, indicative of the presence of $\mathrm{Mg}$-Bchl a (results not shown). The carotenoids were not identified, but TLC of the extracts showed some variability in the pigments of the Erythrobacter/Porphyrobacter/Erythromicrobium group, although two predominant polar carotenoids were present in all strains (TLC profiles of pigments of the novel isolates are available as supplementary material in IJSEM Online at http://ijs.sgmjournals.org/).

Table 2. Mean fatty acid composition of the type strains of the species of the Erythrobacter/Erythromicrobium/Porphyrobacter group and strain ALC-2 ${ }^{\top}$

Fatty acid compositions were determined at $37^{\circ} \mathrm{C}$ as well as at the optimum growth temperature for each strain.

\begin{tabular}{|c|c|c|c|c|c|c|c|c|c|c|c|c|}
\hline \multirow[t]{2}{*}{ Fatty acid } & \multicolumn{2}{|c|}{ P. tepidarius } & \multicolumn{2}{|c|}{ P. neustonensis } & \multicolumn{2}{|c|}{ ALC-2 ${ }^{T}$} & \multicolumn{2}{|c|}{$\begin{array}{l}\text { Erythrobacter } \\
\text { litoralis }\end{array}$} & \multicolumn{2}{|c|}{$\begin{array}{c}\text { Erythrobacter } \\
\text { longus }\end{array}$} & \multicolumn{2}{|c|}{$\begin{array}{c}\text { Erythromicrobium } \\
\text { ramosum }\end{array}$} \\
\hline & $37^{\circ} \mathrm{C}$ & $45^{\circ} \mathrm{C}$ & $30^{\circ} \mathrm{C}$ & $37^{\circ} \mathrm{C}$ & $37^{\circ} \mathrm{C}$ & $50^{\circ} \mathrm{C}$ & $30^{\circ} \mathrm{C}$ & $37^{\circ} \mathrm{C}$ & $30^{\circ} \mathrm{C}$ & $37^{\circ} \mathrm{C}$ & $30^{\circ} \mathrm{C}$ & $37^{\circ} \mathrm{C}$ \\
\hline $12: 0$ & - & - & - & - & - & - & - & $1 \cdot 1$ & - & - & - & $0 \cdot 4$ \\
\hline $14: 0$ & $0 \cdot 4$ & $0 \cdot 2$ & $0 \cdot 3$ & $0 \cdot 8$ & - & - & $0 \cdot 7$ & $1 \cdot 1$ & $0 \cdot 2$ & - & $0 \cdot 2$ & $0 \cdot 6$ \\
\hline $15: 0$ & $0 \cdot 5$ & - & $0 \cdot 3$ & - & $0 \cdot 8$ & $1 \cdot 3$ & $0 \cdot 3$ & - & $1 \cdot 2$ & $1 \cdot 2$ & $3 \cdot 4$ & $2 \cdot 9$ \\
\hline $16: 0$ & $16 \cdot 2$ & $18 \cdot 4$ & $4 \cdot 3$ & $12 \cdot 6$ & $5 \cdot 0$ & $5 \cdot 7$ & $4 \cdot 3$ & $6 \cdot 5$ & $12 \cdot 5$ & $12 \cdot 8$ & $7 \cdot 4$ & $10 \cdot 3$ \\
\hline $15: 02-\mathrm{OH}$ & - & $0 \cdot 4$ & - & - & $7 \cdot 4$ & $4 \cdot 9$ & - & - & $3 \cdot 9$ & $3 \cdot 5$ & $8 \cdot 2$ & $9 \cdot 7$ \\
\hline $17: 0$ iso & - & - & - & - & - & - & - & - & $0 \cdot 6$ & $0 \cdot 7$ & $0 \cdot 8$ & $0 \cdot 5$ \\
\hline $17: 1 \omega 8 c$ & - & - & - & - & $2 \cdot 9$ & $2 \cdot 7$ & - & - & $4 \cdot 0$ & $4 \cdot 6$ & $4 \cdot 7$ & $2 \cdot 6$ \\
\hline $17: 1 \omega 7 c$ & - & $0 \cdot 6$ & $0 \cdot 6$ & - & - & - & $1 \cdot 7$ & $1 \cdot 5$ & - & - & - & - \\
\hline $16: 02-\mathrm{OH}$ & $0 \cdot 3$ & $0 \cdot 6$ & $1 \cdot 7$ & $1 \cdot 9$ & - & - & $1 \cdot 4$ & $1 \cdot 5$ & $0 \cdot 8$ & $0 \cdot 5$ & $0 \cdot 2$ & - \\
\hline Unknown $^{\star}$ & - & - & $7 \cdot 8$ & $4 \cdot 2$ & - & - & - & - & $11 \cdot 1$ & $12 \cdot 2$ & $1 \cdot 4$ & - \\
\hline $18: 1 \omega 7 c$ & $67 \cdot 7$ & $64 \cdot 8$ & $67 \cdot 0$ & $63 \cdot 9$ & $45 \cdot 5$ & $35 \cdot 3$ & $77 \cdot 2$ & $71 \cdot 9$ & $50 \cdot 6$ & $49 \cdot 1$ & $24 \cdot 1$ & $33 \cdot 5$ \\
\hline $18: 1 \omega 5 c$ & $1 \cdot 9$ & $2 \cdot 2$ & $2 \cdot 6$ & $2 \cdot 4$ & $1 \cdot 2$ & $1 \cdot 0$ & $2 \cdot 7$ & $2 \cdot 1$ & - & - & $0 \cdot 6$ & $0 \cdot 6$ \\
\hline $18: 0$ & $0 \cdot 6$ & $1 \cdot 7$ & $0 \cdot 3$ & - & $1 \cdot 1$ & $1 \cdot 4$ & - & - & $1 \cdot 1$ & $1 \cdot 2$ & $0 \cdot 2$ & - \\
\hline
\end{tabular}

${ }^{\star}$ Unknown fatty acid with equivalent chain length of $17 \cdot 607$. 


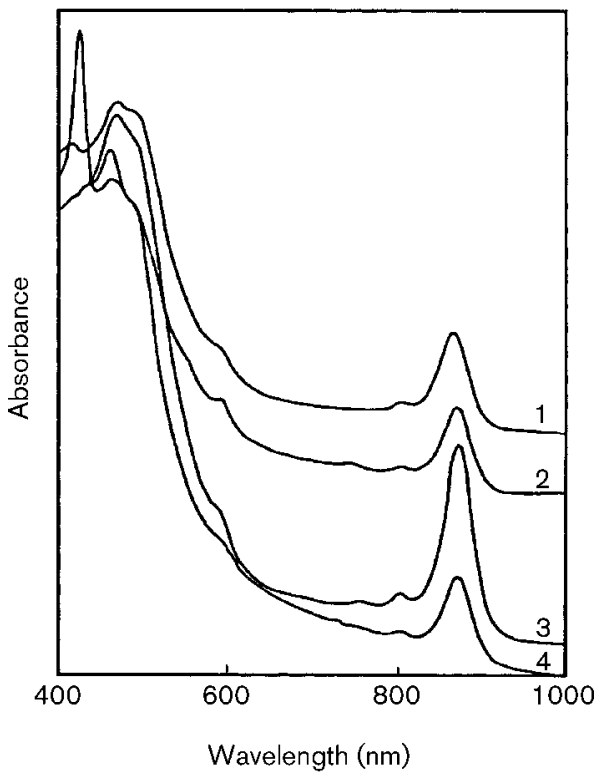

Fig. 3. Absorption spectra of cells of Erythromicrobium ramosum DSM $8510^{\top}$ (1), Erythrobacter litoralis DSM $8509^{\top}$ (2), strain $\mathrm{ALC}-2^{\top}$ (3) and $P$. tepidarius DSM $10594^{\top}$ (4) disrupted ultrasonically in MOPS buffer.

\section{Mean base composition of DNA, DNA-DNA reassociation studies and 165 rRNA gene sequence comparison}

The G+C content of the DNA of the two Porphyrobacter species, Erythrobacter longus, Erythromicrobium ramosum and isolates ALC- ${ }^{\mathrm{T}}$ and ALC-3 ranged between 60 and $67 \mathrm{~mol} \%$. The $\mathrm{G}+\mathrm{C}$ content of strains ALC- ${ }^{\mathrm{T}}$ and ALC-3 was $66 \cdot 2 \mathrm{~mol} \%$. Whole-genome DNA-DNA reassociation values among the species mentioned above were very low, ranging between 21 and $40 \%$ (Table 3). Partial 16S rRNA gene sequences comprising 1413-1414 nt were determined for strain ALC- $2^{\mathrm{T}}$ and the type strains of Erythrobacter longus, Erythrobacter litoralis, Erythromicrobium ramosum,

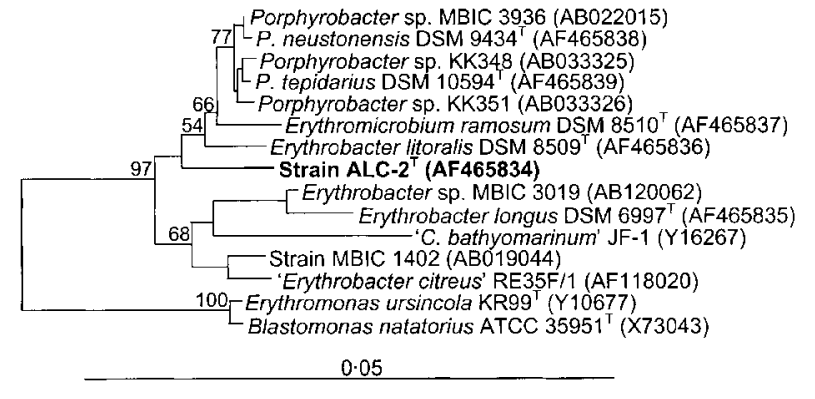

Fig. 4. $16 \mathrm{~S}$ rRNA gene sequence-based neighbour-joining phylogenetic tree showing the position of the novel isolate within the cluster comprising the species of the genera Erythrobacter, Erythromicrobium and Porphyrobacter and their closest relatives. Bar, 5 inferred nucleotide substitutions per $100 \mathrm{nt}$ (as determined by measuring the lengths of the horizontal lines joining any two organisms). Numbers at nodes refer to bootstrap values.

$P$. neustonensis and $P$. tepidarius. The $16 \mathrm{~S}$ rRNA gene sequences of these type strains were redetermined in this study in order to confirm the phylogenetic positions of these strains, which do not cluster in correlation with the accepted nomenclature (e.g. Erythrobacter litoralis and Erythrobacter longus). Comparison of the 16S rRNA gene sequence of strain ALC- $2^{\mathrm{T}}$ with representative sequences of the main lineages within the Proteobacteria indicated that this strain fell within the $\alpha-4$ subclass and more specifically, within the Erythrobacter/Erythromicrobium/Porphyrobacter group. The highest $16 \mathrm{~S}$ rRNA gene sequence similarity to a described taxon was to $P$. tepidarius, at $98 \cdot 3 \%$. 16S rRNA gene sequence similarities to other members of the Erythrobacterl Erythromicrobium/Porphyrobacter group were 95.9-98.3\%. A phylogenetic tree was reconstructed using the $16 \mathrm{~S}$ rRNA gene sequence from each of the type strains of the described species of the Erythrobacter/Erythromicrobium/Porphyrobacter group, seven additional strains for which 16S rRNA gene sequences are available and representative lineages within the $\alpha-4$ subclass of the Proteobacteria (Fig. 4 ). Strain

Table 3. DNA G $+\mathrm{C}$ content and DNA-DNA reassociation between type strains of the Erythrobacter/Erythromicrobium/ Porphyrobacter group

The type strain of Erythrobacter litoralis was not used for comparison of DNA-DNA reassociation.

\begin{tabular}{|lcrrrr|}
\hline Strain/species & G+C content $(\mathbf{m o l} \%)^{*}$ & & & Degree of binding (\%) to: \\
\cline { 3 - 6 } & & $\mathbf{1}$ & $\mathbf{2}$ & $\mathbf{3}$ & $\mathbf{4}$ \\
\hline 1. P. neustonensis & $65 \cdot 6^{a}$ & 100 & & & \\
2. P. tepidarius & $65 \cdot 0^{b}$ & 24 & 100 & & \\
3. Erythrobacter longus & $60 \cdot 0-64 \cdot 0^{b}$ & 21 & 22 & 100 & \\
4. Erythromicrobium ramosum & $64 \cdot 6^{c}$ & 24 & 24 & 25 & 100 \\
5. ALC-2 & $66 \cdot 2^{c}$ & 25 & 35 & 19 & 22 \\
6. ALC-3 & $66 \cdot 2^{c}$ & 31 & 40 & 20 & 21 \\
\end{tabular}

${ }^{\star}$ Data from: $a$, Shiba \& Simidu (1982); b, Hanada et al. (1997); $c$, this study. 
ALC- $2^{\mathrm{T}}$ represented a distinct lineage within the Erythrobacter/Erythromicrobium/Porphyrobacter cluster, having an intermediate position between the Erythrobacter lineage and the other members of this group.

The taxon represented by strain $\mathrm{ALC}-2^{\mathrm{T}}$ was, based on phylogenetic analysis of the $16 \mathrm{~S}$ rRNA gene sequence, closely related to the species of the genera Erythrobacter, Erythromicrobium and Porphyrobacter. Strain ALC $-2^{\mathrm{T}}$ represents an individual lineage that does not cluster with any of the previously described species of the Erythrobacter/Erythromicrobium/Porphyrobacter group. This position is supported by the low bootstrap values within the cluster, which indicate that strain ALC $-2^{\mathrm{T}}$ is not a member of an obvious species of any of the currently described genera. These results are corroborated by the low DNA-DNA reassociation values between the strains.

Based on these results, and the current taxonomic interpretation of this group, we could consider that strains ALC- ${ }^{\mathrm{T}}$ and ALC-3 represent a species of a novel genus. However, the description of taxa of genus level based solely on phylogenetic inference is unacceptable because it leads to taxonomic chaos, since the novel genus would have no differentiating phenotypic characteristics. Alternatively, the ALC strains could represent a species of one of the previously described genera within the Erythrobacter/ Erythromicrobium/Porphyrobacter group. However, the phenotypic characteristics of the ALC isolates, allied to the whole-genome DNA-DNA reassociation values and the phylogenetic analyses, support the idea that these strains could be described as a novel species of any of the genera Erythrobacter, Erythromicrobium or Porphyrobacter, because the novel strains are not obvious members of any of the previously described genera and the genera of this group are not well defined and are phylogenetically intermixed. The possibility of combining the genera Erythrobacter, Erythromicrobium and Porphyrobacter (and the invalidly described 'Citromicrobium') into one genus deserves consideration. In favour of this view, it should be noted that all the species of the genera Erythrobacter, Erythromicrobium and Porphyrobacter produce motile, coccoid and/or rod-shaped cells, although $P$. neustonensis also produces stalked cells and buds, while Erythromicrobium ramosum produces branched cells and ' $C$. bathyomarinum' produces both rod-shaped and branched cells (Yurkov et al., 1999). Strains ALC-2 ${ }^{\mathrm{T}}$ and ALC-3 also produce pleomorphic branched cells on solid media (results not shown), but form rod-shaped cells during exponential phase in liquid medium. The species Erythrobacter longus, Erythrobacter litoralis and 'C. bathyomarinum' are slightly halophilic marine organisms, while the species of Porphyrobacter and Erythromicrobium ramosum originate from freshwater environments. Since ' $C$. bathyomarinum' has been considered a new taxon at the generic level, and is a slightly halophilic marine organism, the argument that the species of the genus Erythrobacter should be considered in a separate genus from the freshwater species of the genera Porphyrobacter and Erythromicrobium cannot be valid. Moreover, several other prokaryotic genera that are also composed of closely related species, notably Thermonema (Tenreiro et al., 1997) and Pyrobaculum (Völkl et al., 1993), contain both slightly halophilic marine and non-halotolerant freshwater species, which leads to the assumption that halophily cannot be used alone to assign the species to a particular genus. The overall fatty acid compositions of all the species (with the exception of 'C. bathyomarinum', for which results are not available) are similar, with a predominance of unsaturated fatty acids, but there is no unique fatty acid pattern within the strains of any of the species of the genera Erythrobacter, Porphyrobacter and Erythromicrobium that could be viewed as indicative of generic distinctiveness. The polar lipid patterns and the quinones are identical. With the possible exception of Erythromicrobium ramosum, the photosynthetic apparatus of all of the species is also identical. All strains, with the exception of ALC- $2^{\mathrm{T}}$ and ALC-3, have similar carotenoid patterns on TLC.

The data we obtained and the information available from the literature lead us to believe that the genera Erythrobacter, Porphyrobacter and Erythromicrobium should be combined into a single genus, i.e. the genus Erythrobacter. However, the view that this group should be classified as one genus may not be appropriate at this time; this leads us to the second alternative, the description of a novel species of an existing genus. The novel species represented by strains ALC- $2^{\mathrm{T}}$ and ALC-3 has phenotypic characteristics that are similar to those of $P$. tepidarius; the growth temperature range of the novel species was slightly higher than that of the type strain of $P$. tepidarius and there were slight differences in the single-carbon-source assimilation patterns. However, strains ALC- ${ }^{\mathrm{T}}$ and ALC-3 and P. tepidarius had substantially different fatty acid compositions. Thus, based on the growth temperature range and the similar singlecarbon-source assimilation patterns, we propose that the species represented by strains ALC- $2^{\mathrm{T}}$ and ALC- 3 should be included in the genus Porphyrobacter as Porphyrobacter cryptus sp. nov.

\section{Description of Porphyrobacter cryptus sp. nov. da Costa, Rainey and Nobre}

Porphyrobacter cryptus (cryp'tus. M.L. masc. adj. cryptus from Gr. adj. kryptos hidden, to indicate the cryptic relationship of this species to the closely related organisms).

Forms short rod-shaped cells of variable width $(0 \cdot 6-1 \cdot 0 \mu \mathrm{m})$ and length $(1 \cdot 0-2 \cdot 8 \mu \mathrm{m})$. Gram stain is negative. Cells are motile by one polar flagellum. Colonies on PE medium are reddish-orange-pigmented. The optimum growth temperature is about $50^{\circ} \mathrm{C}$; growth does not occur at $60^{\circ} \mathrm{C}$. The optimum $\mathrm{pH}$ is between $7 \cdot 5$ and $8 \cdot 0$. Cytochrome oxidaseand catalase-positive. Cells contain Bchl $a$ and carotenoids. The predominant fatty acids are monounsaturated. The major fatty acid is $18: 1 \omega 7 c ; 14: 02-\mathrm{OH}$ and $15: 02-\mathrm{OH}$ are present. The predominant phospholipid is phosphatidylethanolamine. Aerobic and chemo-organotrophic. Growth does not occur under anaerobic conditions in the 
dark or in the light. Nitrate is not reduced to nitrite. Gelatin, starch, xylan, Tweens 20, 40 and 60 and aesculin are hydrolysed. D-Glucose, D-fructose, maltose, sucrose, cellobiose, xylose, pyruvate, arginine and glutamate serve as carbon sources. The $\mathrm{G}+\mathrm{C}$ content of the DNA is $66 \cdot 2 \mathrm{~mol} \%$. Isolated from the hot spring at Alcafache in Central Portugal. The type strain is strain ALC $-2^{\mathrm{T}}(=\mathrm{DSM}$ $12079^{\mathrm{T}}=$ ATCC BAA-386 $\left.{ }^{\mathrm{T}}\right)$. Strain ALC-3 (=DSM 12080) is a reference strain.

\section{ACKNOWLEDGEMENTS}

This work was supported, in part, by the PRAXIS XXI Program (PRAXIS/PCNA/BIO/46/96). We would like to thank Professor Hans Trüper for the etymology of the name of the novel species.

\section{REFERENCES}

Cashion, P., Holder-Franklin, M. A., McCully, J. \& Franklin, M. (1977). A rapid method for the base ratio determination of bacterial DNA. Anal Biochem 81, 461-466.

De Ley, J., Cattoir, H. \& Reynaerts, A. (1970). The quantitative measurement of DNA hybridization from renaturation rates. Eur J Biochem 12, 133-142.

Felsenstein, J. (1993). PHYLIP (phylogenetic inference package) version 3.5.1. Distributed by the author. Department of Genetics, University of Washington, Seattle, USA.

Fuerst, J. A., Hawkins, J. A., Holmes, A., Sly, L. I., Moore, C. J. \& Stackebrandt, E. (1993). Porphyrobacter neustonensis gen. nov., sp. nov., an aerobic bacteriochlorophyll-synthesizing budding bacterium from fresh water. Int J Syst Bacteriol 43, 125-134.

Hanada, S., Kawase, Y., Hiraishi, A., Takaichi, S., Matsuura, K., Shimada, K. \& Nagashima, K. V. P. (1997). Porphyrobacter tepidarius sp. nov., a moderately thermophilic aerobic photosynthetic bacterium isolated from a hot spring. Int J Syst Bacteriol 47, 408-413.

Heimbrook, M. E., Wang, W. L. L. \& Campbell, G. (1989). Staining bacterial flagella easily. J Clin Microbiol 27, 2612-2615.

Jukes, T. H. \& Cantor, C. R. (1969). Evolution of protein molecules. In Mammalian Protein Metabolism, pp. 21-132. Edited by $\mathrm{H}$. N. Munro. New York: Academic Press.

Liaaen-Jensen, S. \& Jensen, A. (1971). Quantitative determination of carotenoids in photosynthetic tissues. Methods Enzymol 23, 586602 .

Maidak, B. L., Cole, J. R., Parker, C. T., Jr \& 11 other authors (1999). A new version of the RDP (Ribosomal Database Project). Nucleic Acids Res 27, 171-173.

Marmur, J. (1961). A procedure for the isolation of deoxyribonucleic acid from micro-organisms. J Mol Biol 3, 208-218.

Mesbah, M., Premachandran, U. \& Whitman, W. B. (1989). Precise measurement of the $\mathrm{G}+\mathrm{C}$ content of deoxyribonucleic acid by highperformance liquid chromatography. Int J Syst Bacteriol 39, 159-167.

Moreira, C., Rainey, F. A., Nobre, M. F., da Silva, M. T. \& da Costa, M. S. (2000). Tepidimonas ignava gen. nov., sp. nov., a new chemolithoheterotrophic and slightly thermophilic member of the $\beta$-Proteobacteria. Int J Syst Evol Microbiol 50, 735-742.
Prado, A., da Costa, M. S. \& Madeira, V. M. C. (1988). Effect of growth temperature on the lipid composition of two strains of Thermus sp. J Gen Microbiol 134, 1653-1660.

Rainey, F. A., Ward-Rainey, N., Kroppenstedt, R. M. \& Stackebrandt, E. (1996). The genus Nocardiopsis represents a phylogenetically coherent taxon and a distinct actinomycete lineage: proposal of Nocardiopsaceae fam. nov. Int J Syst Bacteriol 46, 1088-1092.

Reasoner, D. J. \& Geldreich, E. E. (1985). A new medium for the enumeration and subculture of bacteria from potable water. Appl Environ Microbiol 49, 1-7.

Santos, M. A., Williams, R. A. D. \& da Costa, M. S. (1989). Numerical taxonomy of Thermus isolates from hot springs in Portugal. Syst Appl Microbiol 12, 310-315.

Shiba, T. \& Simidu, U. (1982). Erythrobacter longus gen. nov., sp. nov., an aerobic bacterium which contains bacteriochlorophyll $a$. Int J Syst Bacteriol 32, 211-217.

Silva, M. T. \& Macedo, P. M. (1983). The interpretation of the ultrastructure of mycobacterial cells in transmission electron microscopy of ultrathin sections. Int J Lepr Other Mycobact Dis 51, 225-234.

Silva, M. T. \& Macedo, P. M. (1987). Improved Thiéry staining for the ultrastructural detection of polysaccharides. J Submicrosc Cytol 19, 677-681.

Takamiya, K., Iba, K. \& Okamura, K. (1987). Reaction center complex from an aerobic photosynthetic bacterium, Erythrobacter Och 114. Biochim Biophys Acta 890, 127-133.

Tenreiro, S., Nobre, M. F., Rainey, F. A., Miguel, C. \& da Costa, M. S. (1997). Thermonema rossianum sp. nov., a new thermophilic and slightly halophilic species from saline hot springs in Naples, Italy. Int J Syst Bacteriol 47, 122-126.

Tindall, B. J. (1989). Fully saturated menaquinones in the archaebacterium Pyrobaculum islandicum. FEMS Microbiol Lett 60, 251-254.

Völkl, P., Huber, R., Drobner, E., Rachel, R., Burggraf, S., Trincone, A. \& Stetter, K. O. (1993). Pyrobaculum aerophilum sp. nov., a novel nitrate-reducing hyperthermophilic archaeum. Appl Environ Microbiol 59, 2918-2926.

Williams, R. A. D. \& da Costa, M. S. (1992). The genus Thermus and related microorganisms. In The Prokaryotes, 2nd edn, pp. 3745-3753. Edited by A. Balows, H. G. Trüper, M. Dworkin, W. Harder \& K. H. Schleifer. New York: Springer.

Yurkov, V., Stackebrandt, E., Holmes, A. \& 7 other authors (1994). Phylogenetic positions of novel aerobic, bacteriochlorophyll a-containing bacteria and description of Roseococcus thiosulfatophilus gen. nov., sp. nov., Erythromicrobium ramosum gen. nov., sp. nov., and Erythrobacter litoralis sp. nov. Int J Syst Bacteriol 44, 427-434.

Yurkov, V., Stackebrandt, E., Buss, O., Vermeglio, A., Gorlenko, V. \& Beatty, J. T. (1997). Reorganization of the genus Erythromicrobium: description of "Erythromicrobium sibiricum" as Sandaracinobacter sibiricus gen. nov., sp. nov., and of "Erythromicrobium ursincola" as Erythromonas ursincola gen. nov., sp. nov. Int J Syst Bacteriol 47, $1172-1178$.

Yurkov, V. V., Krieger, S., Stackebrandt, E. \& Beatty, J. T. (1999). Citromicrobium bathyomarinum, a novel aerobic bacterium isolated from deep-sea hydrothermal vent plume waters that contains photosynthetic pigment-protein complexes. J Bacteriol 181, 45174525 . 